НАУКОВИЙ ВІСНИК

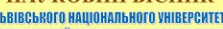
РИнАРНОї МЕДИИНИ ТА БОтЕКНОЛО Scientific messenger of Livi National University of
Veterinary Meticicie and Biotechnologges

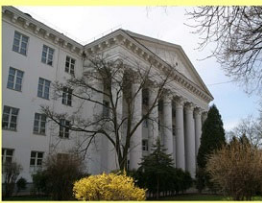

СЕРІЯ “ЕКОНОМІчн НАУКИ"

Том 21 № 93 2019
Науковий вісник Аьвівського національного університету ветеринарної медицини та біотехнологій імені С.3. Гжицького. Серія: Економічні науки

\author{
Scientific Messenger of Lviv National University \\ of Veterinary Medicine and Biotechnologies. \\ Series: Economical Sciences
}

\title{
Operational analysis of agricultural production: state, problems, prospects
}

\author{
K.I. Posylaieva, S.V. Sherstiuk, V.V. Posylaiev \\ Kharkiv National Agrarian University named after V.V. Dokuchaiev, Kharkiv, Ukraine
}

Article info

Received 05.09.2019

Received in revised form 03.10 .2019

Accepted 04.10.2019

Kharkiv National Agrarian University named after

V.V. Dokuchaiev, Kharkiv region Kharkiv district, "Dokuchaevske2", 62483, Ukraine.

Tel.: +38-095-138-73-66

E-mail: office@knau.kharkov.ua
Posylaieva, K.I., Sherstiuk, S.V., \& Posylaiev, V.V. (2019). Operational analysis of agricultural production: state, problems, prospects. Scientific Messenger of Lviv National University of Veterinary Medicine and Biotechnologies. Series: Economical Sciences, 21(92), 23-26. doi: $10.32718 /$ nvlvet-e 9305

In modern agricultural production, economic analysis is increasing for the perception of operational management decisions. The purpose of this article is to justify the expediency and necessity of conducting operational economic analysis as a special element of operational management in all agricultural enterprises to increase the efficiency of their activities. The article defines the essence of operational economic analysis of agricultural production. Three of its subspecies considered in detail: periodic, operational and situational analysis. Specificity of agriculture determines the features of organization and conducting of operational analysis. Because in agricultural production, firstly, the periods of implementation of costs and outputs do not coincide; and secondly, the process of production for certain types of products is stretched over time. Therefore, conducting operational analysis by industry characterize by its specifics. In particular, in crop production, operational analysis carry out during the periods of basic agrotechnical works: preplanting of soil and sowing; care of crops; harvesting. We have determined that the main feature of operational analysis is the continuity and rhythm of analytical work throughout the year (daily, monthly). Unfortunately, today it doesn't solve as for small, as for large agricultural enterprises also. We have made substantiated conclusions about the peculiarities of the operational analysis of agricultural production and the necessity of its implementation in all agricultural enterprises.

Key words: operational economic analysis, agricultural production, features of periodic, operational and situational analysis, operational management.

\section{Оперативний аналіз сільськогосподарського виробництва: стан, проблеми, перспективи}

\author{
К.І. Посилаєва, С.В. Шерстюк, В.В. Посилаєв
}

Харківський національний аграрний університет ім. В.В. Докучаєва, м. Харків, Украӥна

\footnotetext{
Визначено сутність оперативного економічного аналізу та відображені особливості його методики для сільськогосподарських підприємств. 3'ясовано, що оперативний аналіз сільськогосподарських підприємствах має три підвиди: періодичний, поопераційний та ситуачійний. Специфіка сільського господарства обумовлює особливості його організаиії і проведення, оскільки в сільськогосподарському виробнищтві, по-перше, періоди здійснення витрат і виходу продукиії не збігаються; по-друге, прочес виробництва окремих видів продукиї розтягнутий у часі. Тому проведення оперативного аналізу за галузями має свою специфіку. Зокрема, у рослинництві оперативний аналіз здійснюють за періодами основних агротехнічних робіт: передпосівна обробка трунту і сівба; догляд за посівами; збирання урожаю. Встановлено, що основною рисою оперативного аналізу є безперервність і ритмічність аналітичної роботи протягом усього року (щоденно, щомісячно), чого, на жаль, сьогодні бракує не тільки малим, а й великим сільськогосподарським підприємствам. Зроблені обтрунтовані висновки щодо особливостей оперативного аналізу сільськогосподарського виробництва та необхідності його проведення у всіх сільськогосподарських підприємствах.
}

Ключові слова: оперативний економічний аналіз, сільськогосподарське виробнищтво, особливості періодичного, пооперачійного та ситуаційного аналізу, оперативне управління. 


\section{Вступ}

В сучасних умовах сільськогосподарського виробництва зростає роль економічного аналізу для оцінки обгрунтованості оперативних управлінських рішень, оскільки найменші прорахунки і упущення в планах, управлінських рішеннях призводять до значних втрат виробничих можливостей, посилюють ризик у виробництві, загрожують зривом виробничої програми та зниженням темпів розвитку підприємства. При цьому інтереси оперативного управління потребують високої оперативності аналізу, що зумовлює необхідність здійснення глибокого аналізу не тільки минулих, а й поточних господарських процесів з метою оперативного прогнозування і розробки методів впливу на виробництво.

Дослідження сучасного стану організації економічного аналізу загалом і оперативного зокрема свідчить, що тільки десь у $30 \%$ великих сільськогосподарських підприємств Харківської області він більшменш організований. Що стосується невеликих (малих) сільськогосподарських підприємств, загальна чисельність яких значно перевищує кількість великих підприємств, то систематичного, постійного аналізу ні виробничого процесу, ні господарської діяльності загалом у них не проводиться. Найчастіше в таких господарствах здійснюється підсумковий (заключний) аналіз основних показників їхьої діяльності за рік або проводять необхідні розрахунки певних фінансових коефіцієнтів, щоб обгрунтувати його кредитоспроможність 3 метою одержання кредиту. Оскільки обсяг такої аналітичної роботи невеликий, то його здійснює зазвичай головний бухгалтер, хоча якість такого аналізу не завжди відповідає сучасним вимогам.

Основний недолік заключного аналізу полягає в тому, що його результати не використовують в оперативному управлінні виробництвом, тобто для корегування i регулювання виробництва протягом року. Тому виникає необхідність у проведенні оперативного економічного аналізу, можливості якого значно розширилися при комп'ютеризації облікового процесу, який забезпечує аналіз важливою базою оперативних даних.

Аналіз останніх досліджень $і$ публікаичій. Дослідження щодо сутності, теоретичних основ та методики оперативного аналізу, як невід'ємної функції управління, знайшли своє відображення у роботах провідних науковців-аналітиків. Зокрема М.І. Баканов і А.Д. Шеремет стверджують, що оперативний аналіз являє собою систему повсякденного вивчення виконання планових завдань 3 метою швидкого втручання при необхідності у процес виробництва для забезпечення безперервного і ефективного функціонування господарського комплексу (Lysenko, 2018). Група науковців на чолі з професором В.К. Горкавим, погоджуючись за суттю з визначенням змісту оперативного аналізу, додають, що його головним завданням є постійний контроль раціональності функціонування господарської системи, а також своєчасного виявлення і використання поточних внутрішньогосподарсь- ких резервів з метою забезпечення виконання бізнеспланів (Horkavyi et al., 2000).

А.М. Лисенко, досліджуючи особливості організації економічного аналізу у фермерських господарствах, зазначає, що сьогодні у переважній більшості фермерських господарств оперативний аналіз не проводять взагалі, а підсумковий аналіз результатів господарювання проводять формально, на примітивному рівні, часто ігноруючи економічні закони та орієнтуючись на нарощування прибутку (Lysenko, 2018). На жаль, така ситуація в більшості малих сільськогосподарських підприємств.

Причина, на нашу думку, полягає в тому, що у невеликому за розмірами підприємстві економічну роботу, зазвичай, координують керівник господарства i бухгалтер. Бухгалтер несе відповідальність за відображення достовірної інформації про господарську діяльність в облікових регістрах, складання і подання звітності та забезпечення відповідності інформації при ії відображенні у різних формах звітності шляхом часткової реалізації функції контролю у процесі формування масиву даних. Керівник, як особа, що приймає рішення, повинен здійснювати економічний аналіз, але за різних причин найчастіше ці функції перекладаються на того ж бухгалтера і в результаті аналіз проводиться поверхнево.

Водночас варто зауважити, що в сучасних публікаціях, на наш погляд, практично не знаходить відображення проблема відсутності економічного аналізу процесу виробництва у сільськогосподарських підприємствах, i, як наслідок, - бракує не тільки оперативного, а нерідко й перспективного прогнозування їхього розвитку, а результатом такого стану є неефективне використання ресурсів, зростання витрат i втрати ринкових позицій.

Формулювання цілей статті. Ринкова економіка обумовила диференціацію економічного аналізу на внутрішній управлінський та зовнішній фінансовий аналіз. Головне призначення внутрішнього управлінського аналізу - це інформаційно-аналітичне забезпечення функції управління підприємством. При цьому за змістом процесу управління виокремлюють перспективний (прогнозний), оперативний та поточний аналіз, що відповідає часовим етапам основних функцій управління:

- попереднього управління - функція планування;

- оперативного управління - функція організації управління;

- заключний етап управління - функція контролю.

Таким чином, оперативний аналіз спрямований на вирішення завдань, які стоять перед оперативним управлінням господарською системою.

Тому метою даної статті $є$ обгрунтування доцільності та необхідності проведення оперативного економічного аналізу як особливого елементу оперативного управління у всіх сільськогосподарських підприємствах для посилення додаткових можливостей розвитку виробництва i підвищення його ефективності. 


\section{Результати та їх обговорення}

Оперативний економічний аналіз здійснюють за будь-який проміжок часу в межах року, його результати та виявлені резерви використовують безпосередньо в поточному господарському процесі. Паралельне існування планування й обліку зумовлює необхідність порівняння наявних у них даних і здійснення контролю за виконанням планів. Відсутність такого контролю призводить до управлінських помилок та невиконання планів і договорів.

Водночас варто зазначити, що часто навіть суворий контроль за дотриманням виробничої програми не виключає виникнення відхилень фактичних результатів діяльності від їх планових чи договірних параметрів, що може пояснюватися об'єктивними причинами, які вимагають глибокого дослідження для усунення в оперативному порядку або для врахування в подальшій діяльності. Крім того, підвищення інтенсифікації, ефективності виробництва і якості продукції не досягається одним контролем за дотриманням планів, а вимагає глибокого й всебічного дослідження резервів виробництва, що виникли в ході виробничого процесу.

3 теоретичної точки зору у сільськогосподарському виробництві можна здійснювати три підвиди оперативного аналізу: періодичний, поопераційний та ситуаційний. На практиці найбільшого поширення набув аналіз за певні проміжки часу. Часовий інтервал в аналізі визначається особливостями сільськогосподарського виробництва, періодичністю в плануванні та звітності. Відомий економіст-аналітик Г.В. Савицька виділяє такі:

- Результати господарської діяльності сільськогосподарських підприємств значною мірою залежать від природньо-кліматичних умов. Тому для отримання правильних висновків про результати господарської діяльності показники поточного року доцільно порівнювати з середніми даними за попередні 3-5 років.

- Для сільського господарства характерна сезонність виробництва. У звязку 3 цим протягом року неритмічно використовуються трудові ресурси, техніка, матеріали, нерівномірно реалізується продукція, надходить виторг. Цю особливість необхідно враховувати при аналізі забеспеченості та використання виробничих засобів.

- В сільському господарстві процес виробництва досить тривалий i не збігається 3 робочим періодом. Більшість показників можна розрахувати тільки по закінченні року. У зв’язку з цим найбільш повний аналіз у рослинництві можна зробити тільки за результатами року, а протягом року аналізують виконання плану агротехнічних заходів за періодами сільськогосподарських робіт.

- Сільськогосподарське виробництво має справу 3 живими організмами. Тому на рівень його розвитку справляють вплив не тільки економічні, а й біологічні, хімічні та фізичні закони, що ускладнює вимір впливу факторів на результати господарської діяльності.

- Основним засобом виробництва в сільському господарстві $є$ земля, природні особливості якої нерозривно пов'язані з кліматичними умовами. Завданням аналізу $є$ обгрунтування шляхів найбільш ефективного використання землі.

- В сільському господарстві значна кількість однотипових підприємств, які виробляють однакові види продукції, що суттєво підвищує їхню конкуренцію. Але з точки зору економічного аналізу є широка база для порівняння, що дозволяє використовувати різні прийоми і методи (Savickaja, 2004).

Специфіка сільськогосподарського виробництва обумовлює й особливості організації і проведення оперативного аналізу діяльності аграрних підприємств, оскільки в сільськогосподарському виробництві, по-перше, періоди здійснення витрат і виходу продукції не збігаються; по-друге, процес виробництва окремих видів продукції розтягнутий у часі (вирощування сільськогосподарських культур, вирощування худоби на м'ясо). Тому проведення оперативного аналізу за галузями має свою специфіку. Зокрема, у рослинництві оперативний аналіз здійснюють за періодами основних агротехнічних робіт, передбачених технологічними картами вирощування окремих сільськогосподарських культур: передпосівна обробка грунту і сівба; догляд за посівами; збирання урожаю. Значно ширше можна використати щоквартальний аналіз загалом по господарству, коли аналізують виконання плану з витрат виробництва і обсягу виконаних робіт. У тваринництві такий аналіз здійснюється більш комплексно, оскільки ця галузь має ритмічніший вихід продукції виробництва. Тут виникає можливість не тільки здійснення аналізу виконання виробничої програми з обсягів продукції, а й визначення суми матеріальних витрат.

Проте, як ми вже зазначали, у сільськогосподарському виробництві через певні обставини періоди i квартали за своїми виробничими умовами або взагалі не повторюються (рослинництво), або мають істотні відмінності (тваринництво). Тому на практиці в оперативному управлінні результати періодичного оперативного аналізу використовуються не повністю, а лише як орієнтири для корегування в наступних періодах.

Частково таких недоліків позбавлений щомісячний економічний аналіз, методика якого аналогічна щоквартальному, при тому, що період втричі коротший. Особливо ефективний такий аналіз у тваринництві, де $\epsilon$ певна база нормативно-планової та облікової інформації. Однак суттєвого впливу на хід виробничого процесу такий аналіз також не має.

Такі ж недоліки, як і квартальний, має щомісячний аналіз й у рослинництві, оскільки кожна агротехнічна операція в рільництві здійснюється в межах місяця. Тобто кожний наступний місяць відрізняється від попереднього набором сільськогосподарських робіт та технологічних операцій i, природно, результати 
аналізу технології і витрат за один місяць не можуть істотно вплинути на хід виробництва в наступному.

Найбільш ефективний $з$ точки зору дієвості аналітичних результатів, повнішого їх використання в оперативному управлінні виробництвом є щоденний аналіз. Базою даних для щоденного аналізу є оперативні і календарні плани-графіки, дані первинного i оперативного обліку, результати спостережень. Найширше він використовується при контролі за дотриманням виробничої програми, використанням виробничих ресурсів (кормів, насіння, техніки), виконанням планів збирання врожаю, реалізації продукції, виконання договірних зобов'язань тощо.

Основною рисою оперативного аналізу є безперервність і ритмічність аналітичної роботи протягом усього року (щоденно, щомісячно), чого, на жаль, сьогодні бракує не тільки малим, а й великим сільськогосподарським підприємствам.

Поглиблення оперативного аналізу, забезпечення повноти використання його результатів для прийняття оперативних управлінських рішень спрямовано передусім на дослідження господарського процесу, який у сільськогосподарському виробництві складається 3 певних операцій. Тому суть поопераційного аналізу полягає в глибокому дослідженні ресурсного (матеріального) й організаційного забезпечення та здійснення робочих і господарських операцій, виявлення причин відхилення їх фактичного ходу від запланованих параметрів, впливу факторів i їх причиннонаслідкових зв'язків, що розкривають резерви підвищення ефективності й якості виробництва.

В оперативному управлінні використання результатів поопераційного аналізу зводяться в основному до оперативної переорієнтації і корегування технології операцій та їх заміні 3 двох причин: як вихід 3 скрутного становища внаслідок несприятливої ситуації, що склалася; як поліпшення поопераційної технології при сприятливих ситуаціях. Особливо ефективний щоденний поопераційний аналіз тривалих, певною мірою одноманітних по днях господарських процесів (заготівля кормів, збирання врожаю).

Важливим різновидом оперативного аналізу є ситуаційний аналіз, суть якого полягає в попередньому, завчасному дослідженні причин і передумов виникнення ситуацій, факторів, що їх зумовлюють, і причинно-наслідкових факторних зв'язків; розробці заходів, що запобігають негативному впливу ситуацій або згладжують їх і передбачають позитивні дії. Ситуаційний аналіз порівняно з поопераційним є комплексним і досліджує не тільки технологічні, а й технічні, соціальні, біологічні та інші фактори в їх причиннонаслідковому зв'язку.
На практиці такий аналіз у сільськогосподарському виробництві проводять, якщо умови відрізняються від запланованих або нормальних. Наприклад, проведений незадовго до збирання ранніх зернових ситуаційний аналіз показав, що під дією кліматичних умов очікується одночасне достигання й інших культур, тому керівництву необхідно забезпечити додаткові збиральні засоби, трудові ресурси тощо.

\section{Висновки}

Оперативний аналіз є ефективним засобом виконання виробничої програми і бізнес-планів. При ньому досліджується розвиток господарського процесу за поточний період, а його результати є базою для прийняття оперативних управлінських рішень, спрямованих на усунення виявлених недоліків, покращення виробничих ситуацій, а загалом - підвищення ефективності виробництва.

На наш погляд, в сільськогосподарських підприємствах доцільно забезпечити (або відновити) посаду економіста-аналітика, оскільки численність, стохастичність і різноманітність господарських ситуацій, що складаються у процесі виробництва під дією різних факторів, зумовлюють додатковий обсяг аналітичних робіт, здійснення якого має переважно сезонний, адекватний сільськогосподарському виробництву характер. Така робота вимагає від фахівця певної методичної підготовки, а головне - своєчасності надання результатів аналізу для оперативного управління.

\section{References}

Bakanov, M.I., \& Sheremet, A.D. (2002). Teorija jekonomicheskogo analiza. Uchebnik. 4-e izd., dop. i pererab. M.: Finansy i statistika (in Russian).

Horkavyi, V.K., Posylaieva, K.I., \& Honcharenko, N.H. (2000). Teoriia ekonomichnoho analizu. Navch. posibn. Kharkiv. Red. vydavn. viddil KhDAU im. V.V. Dokuchaieva (in Ukrainian).

Lysenko, A.M. (2018). Osoblyvosti orhanizatsii ekonomichnoho analizu u fermerskykh hospodarstvakh. Hlobalni pryn-tsypy finansovoho, oblikovoho ta analitychnoho zabezpechennia ahrarnoho sektora ekonomiky: materialy Mizhnar. nauk.-prakt. konf., 8-9 lystopada 2018 r. Vyp. 1. Khark. nats. ahrar. un-t. Kharkiv: KhNAU, 284-287 (in Ukrainian).

Savickaja, G.V. (2004). Analiz hozjajstvennoj dejatel'nosti predprijatij APK. Uchebnik. 6-e izd.,ispr. i dop. Mn.: Novoe znanie (in Russian). 